\title{
Late Holocene droughts in the Fertile Crescent recorded in a speleothem from northern Iraq
}

Article

Published Version

Flohr, P., Fleitmann, D., Zorita, E., Sadekov, A., Cheng, H., Bosomworth, M., Edwards, L., Matthews, W. and Matthews, R. (2017) Late Holocene droughts in the Fertile Crescent recorded in a speleothem from northern Iraq. Geophysical Research Letters, 44 (3). pp. 1528-1536. ISSN 1944-8007 doi: https://doi.org/10.1002/2016GL071786 Available at https://centaur.reading.ac.uk/68879/

It is advisable to refer to the publisher's version if you intend to cite from the work. See Guidance on citing.

To link to this article DOI: http://dx.doi.org/10.1002/2016GL071786

Publisher: American Geophysical Union

All outputs in CentAUR are protected by Intellectual Property Rights law, including copyright law. Copyright and IPR is retained by the creators or other copyright holders. Terms and conditions for use of this material are defined in the End User Agreement. 


\section{CentAUR}

Central Archive at the University of Reading

Reading's research outputs online 


\section{Geophysical Research Letters}

\section{RESEARCH LETTER}

10.1002/2016GL071786

\section{Key Points:}

- A long-term drying trend was present in the Fertile Crescent from at least 950 C.E.

- The recent droughts were extreme compared to the mean climate and superimposed on the long-term aridification

- The long-term trend is not captured by tree ring records or climate models

Supporting Information:

- Supporting Information S1

- Table S1

- Table S2

- Table S3

- Table S4

- Table S5

Correspondence to: P. Flohr and D. Fleitmann, p.flohr@reading.ac.uk;

d.fleitmann@reading.ac.uk

\section{Citation:}

Flohr, P., D. Fleitmann, E. Zorita, A. Sadekov, H. Cheng, M. Bosomworth, L. Edwards, W. Matthews, and R. Matthews (2017), Late Holocene droughts in the Fertile Crescent recorded in a speleothem from northern Iraq, Geophys. Res. Lett., 44, doi:10.1002/2016GL071786.

Received 31 OCT 2016 Accepted 20 JAN 2017

\section{Late Holocene droughts in the Fertile Crescent recorded in a speleothem from northern Iraq}

\author{
Pascal Flohr $^{1}$ (D), Dominik Fleitmann ${ }^{1}$ (D) Eduardo Zorita ${ }^{2}$ (D) Aleksey Sadekov ${ }^{3}$ (D) Hai Cheng ${ }^{4,5}$ (D), \\ Matt Bosomworth ${ }^{1}$, Lawrence Edwards ${ }^{5}$, Wendy Matthews ${ }^{1}$ (D), and Roger Matthews ${ }^{1}$ \\ ${ }^{1}$ Department of Archaeology and Centre for Past Climate Change, University of Reading, Reading, UK, ${ }^{2}$ Institute of Coastal \\ Research, Helmholtz-Zentrum Geesthacht, Geesthacht, Germany, ${ }^{3}$ Department of Earth Sciences, University of Cambridge, \\ Cambridge, UK, ${ }^{4}$ Institute of Global Environmental Change, Xi'an Jiaotong University, Xi'an, China, ${ }^{5}$ Department of Earth \\ Sciences, University of Minnesota, Minneapolis, Minnesota, USA
}

Abstract Droughts have had large impacts on past and present societies. High-resolution paleoclimate data are essential to place recent droughts in a meaningful historical context and to predict regional future changes with greater accuracy. Such records, however, are very scarce in the Middle East in general, and the Fertile Crescent in particular. Here we present a 2400 year long speleothem-based multiproxy record from Gejkar Cave in northern Iraq. Oxygen and carbon isotopes and magnesium are faithful recorders of effective moisture. The new Gejkar record not only shows that droughts in 1998-2000 and 2007-2010, which have been argued to be a contributing factor to Syrian civil war, were extreme compared to the current mean climate, but they were also superimposed on a long-term aridification trend that already started around or before 950 C.E. (Common Era). This long-term trend is not captured by tree ring records and climate models, emphasizing the importance of using various paleoclimate proxy data to evaluate and improve climate models and to correctly inform policy makers about future hydroclimatic changes in this drought-prone region.

\section{Introduction}

The impact of rising temperatures on precipitation remains uncertain in many parts of the world [Dai, 2013; Ljungqvist et al., 2016; Sheffield et al., 2012]. The "dry gets drier, wet gets wetter" paradigm [Held and Soden, 2006] has been rejected for as much as $90 \%$ of land areas [Greve et al., 2014]. In the Middle East, climate models predict an increase in the frequency and intensity of droughts due to a northward displacement of storm tracks and the resultant decline in cold season precipitation [Christensen et al., 2013]. Located in the Middle East, the Fertile Crescent (FC; Figure 1) is particularly vulnerable to droughts as water is a scarce resource due to the rising demand for irrigation and domestic use, poor water management, and recent multiyear droughts [Joodaki et al., 2014; Kelley et al., 2015]. The dramatic socioeconomic effects immediately following the 2007-2010 drought in Syria and Iraq underline the importance of water for political stability in this region. This persistent drought in Syria and the wider FC led to a significant decrease in agricultural production [Trigo et al., 2010] and caused the displacement of $\sim 1.5$ million people from rural areas in northeastern Syria, which in turn increased social tensions in Syria's cities (e.g., unemployment, poverty, and corruption). The drought is therefore considered as one of the contributing factors to the onset of the Syrian civil war [Gleick, 2014; Kelley et al., 2015; but see de Châtel, 2014].

Clearly, the Middle East is a climate change "hot spot" [Giorgi, 2006] and it is therefore crucial to understand the forcing mechanisms behind droughts. However, instrumental records from this area cover only the last few decades and are therefore much too short to capture the full range of hydrological extremes. They are also not suited to place the current droughts into a broader and meaningful historical context. Near-instrumental paleoclimate records from the Middle East are also crucial for meaningful data-model comparisons [Braconnot et al., 2012] and determination of the causes, frequency, and duration of droughts. Such records, however, are rare and distinct spatiotemporal gaps exist, particularly in the FC (Figure 1). To fill this gap, we present a nearly continuous 2400 year long and highly resolved multiproxy stalagmite record from Gejkar Cave in northern Iraq (Figure 1).

\section{Cave Location and Modern Climatology}

Gejkar Cave $\left(35^{\circ} 48^{\prime} 15.9^{\prime \prime} \mathrm{N}, 45^{\circ} 09^{\prime} 52.3^{\prime \prime} \mathrm{E}, 650 \mathrm{~m}\right.$ above sea level) is located in the Pira Magroon mountains in the Zagros foothills, $35 \mathrm{~km}$ northwest of Sulamaniyah and $85 \mathrm{~km}$ northeast of Kirkuk in the Kurdish Regional
(C2017. American Geophysical Union. All Rights Reserved. 


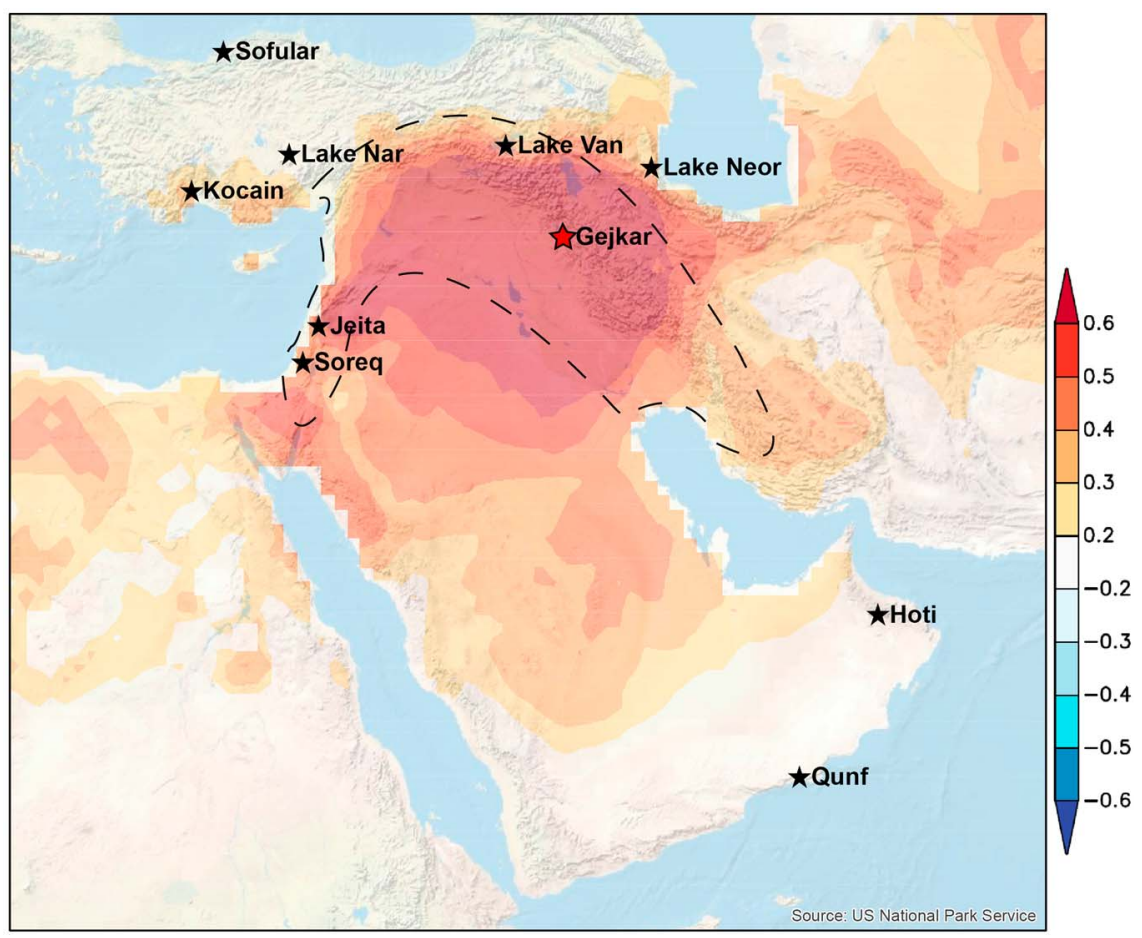

Figure 1. Map of the Middle East and Fertile Crescent (dashed line). Locations of currently available high-resolution and well-dated paleoclimate records (black stars) covering the last 2500 years and Gejkar Cave (red star). Colors indicate the correlation of the SPEI drought index [Vicente-Serrano et al., 2010] (see section 3) in the Gejkar $0.5^{\circ}$ grid cell with other areas in the Middle East, generated in the KNMI Climate Explorer [van Oldenborgh, 2016].

Government area in northern Iraq. Gejkar is a shallow cave (438 m long) with a bedrock thickness of only $20 \mathrm{~m}$ and responds quickly to seasonal changes in surface rainfall. The surface above the cave does not appear to be affected by human activity and vegetation consists of shrubs and grasses.

As in the rest of the FC, $98 \%$ of precipitation in the area around Gejkar Cave occurs between October and May (82\% November-March; Figure S1 in the supporting information). Total annual (winter) precipitation in the Gejkar $0.5^{\circ}$ grid cell averages $\sim 400 \mathrm{~mm} \mathrm{yr}^{-1}$ and $\sim 680 \mathrm{~mm} \mathrm{yr}^{-1}$ in the hills where Gejkar Cave is located. Precipitation is highly variable on interannual time scales (1901-2014, Climatic Research Unit (CRU) data and meteorological observations [Harris et al., 2014; van Oldenborgh, 2016]). Moisture originates mainly from the eastern Mediterranean and is associated with westward moving storm tracks originating either from the North Atlantic or the eastern Mediterranean [Ulbrich et al., 2012].

\section{Materials and Methods}

An actively growing, $39 \mathrm{~cm}$ long stalagmite (Gej-1) was collected from Gejkar Cave in January 2013. The chronology of Gej-1 is based on a combination of annual layer counts and uranium-series dating $\left({ }^{230}\right.$ Th hereinafter). Annual layer counts and thickness measurements were performed on a high-resolution scan by using ImageJ software (available at https://imagej.nih.gov/ij/). Where laminae were difficult to recognize, an uncertainty of \pm 0.5 year was added, leading to a cumulative error, similar to the approach taken by the ice core community [Rasmussen et al., 2006]. ${ }^{230}$ Th dating was performed by using Thermo-Finnigan Neptune multicollector inductively coupled plasma mass spectrometers at the Xi'an Jaiotong University and the University of Minnesota; the methods are described in detail in Cheng et al. [2013].

A total of 841 stable isotope and almost 24,000 trace element measurements were performed on Gej-1. Samples for stable isotope analysis were taken by using a microdrill at a $0.2 \mathrm{~mm}$ resolution for the upper $20 \mathrm{~mm}$ of Gej-1 ( 1 year resolution) and at a $0.5 \mathrm{~mm}$ resolution for the remaining part ( 2.3 year resolution). Isotope measurements were performed on a Finnigan Delta V Advantage Isotope Ratio Mass Spectrometer (IRMS) coupled to an automated carbonate preparation system (Gasbench II) at the Central Analytical Facility, University of Reading, UK. The precision $(1 \sigma)$ is $\leq 0.1 \%$ ofor $\delta^{13} \mathrm{C}$ and $\leq 0.2 \%$ ofor $\delta^{18} \mathrm{O}$. 
Magnesium (Mg) measurements were performed on the upper half ( $19 \mathrm{~cm}$ ) of Gej-1 at a $0.008 \mathrm{~mm}$ (biweekly) resolution by using laser ablation-inductively coupled plasma mass spectrometry (ICPMS) at the Department of Earth Science, University of Cambridge. This high-resolution depth profiling technique employs an Analyte G2 excimer 219 laser (Teledyne Photon Machines Inc) coupled with a Thermo i-CapQ ICPMS to measure trace metal elemental profiles. Further details on the instrumental setup are provided in Text S1 in the supporting information (see also Tanner et al. [2002]).

Oxygen and carbon isotopes were compared with modern precipitation and temperature observations, which were derived from CRU0.5 gridded data [Harris et al., 2014] via the KNMI Climate Explorer tool [van Oldenborgh, 2016]. To capture agricultural droughts, we use the Standardized Precipitation Evapotranspiration Index (SPEI), as the SPEI index takes not only precipitation and potential evapotranspiration but also time scale features (e.g., runoff and reservoir storage) into account [Vicente-Serrano et al., 2010]. We also compared the Gej-1 isotope record with the self-calibrating Palmer Drought Severity Index (PDSI) [Dai, 2011]. Tigris runoff at Kut in Iraq [United Nations Economic and Social Commission for Western Asia (UN-ESCWA) and Bundesanstalt für Geowissenschaften und Rohstoffe (BGR), 2013] is used as an additional measure for precipitation in its large catchment area, which also includes the Gejkar area.

For the data-model comparison, we have used the output of two global Earth System Models that have participated in the Climate Model Intercomparison Project version 5 (CMIP5) used by the Intergovernmental Panel on Climate Change. The models are the Max-Planck-Institute for Meteorology (Hamburg, Germany), which is denoted MPI-ESM-P [Giorgetta et al., 2013], and the Community Climate System Model version 4 (CCSM4) of the National Centre for Atmospheric Research (Boulder, USA) [Gent et al., 2011]. Both models cover the "past millennium" (850-1849 Common Era (C.E.)) and the historical period (1850-2005 C.E.). The reason of the selection of these two models from the CMIP5 ensemble is that they cover both periods with the very same model version and that the simulations for the historical period were started from the last conditions simulated in the first period (this is not always the case for other CMIP5 models). Forcings were based on Schmidt et al. [2011] and Vieira et al. [2011] (both models), Crowley and Unterman [2013] (MPI-ESM-P), and Gao et al. [2008] (CCSM4). Detailed information is given in Text S2.

\section{Chronology}

The chronology of Gej-1 is based on a total of $13^{230}$ Th dates (Table S1 in the supporting information) and annual layer counts (Table S2 and Figure S2). Almost all ${ }^{230}$ Th ages are in stratigraphic order and in good agreement with the layer counts (9 out of 13), particularly for growth interval II ( 930-2013 C.E.). The annual layer counts and ${ }^{230} \mathrm{Th}$ dating indicate that stalagmite Gej-1 covers the intervals from $\sim 430$ before the Common Era (B.C.E.) to 350 C.E. and from 930 C.E. until collection in January 2013. The $\sim 500$ year long hiatus is mechanical (e.g., earthquake and rockfall from the cave ceiling) rather than climatological, as shown by cutoff growth layers (Figure S3).

\section{Paleoclimatic Interpretation of the Gejkar Proxies}

We suggest that the Gejkar stalagmite is an accurate recorder of fluctuations in effective moisture for four reasons. First, the marked difference in the thickness of annual growth layers between growth interval I ( $\sim 30$ B.C.E to $\sim 350$ C.E; average growth rate is $\left.0.27 \mathrm{~mm} \mathrm{yr}^{-1}\right)$ and II ( 930-2013 C.E.; average growth rate is $0.20 \mathrm{~mm} \mathrm{yr}^{-1}$ ) coincides with the distinct positive shift in mean $\delta^{18} \mathrm{O}$ and $\delta^{13} \mathrm{C}$ values (Figure 2a). In regions with a semiarid to arid climate and strong seasonality, such as northern Iraq, the growth rate and thickness of annual growth layers are often related to effective moisture and drip rates within the cave, with thinner annual layers indicating lower drip rates and reduced effective moisture [e.g., Fleitmann et al., 2004, 2007].

Second, the $\delta^{18} \mathrm{O}, \delta^{13} \mathrm{C}$, and $\mathrm{Mg}$ profiles are similar on decadal to multidecadal time scales (Figures 2a and S4). Especially $\delta^{18} \mathrm{O}$ and $\delta^{13} \mathrm{C}$ are closely related (Spearman correlation coefficient of 0.87; Figure 2), with more negative isotope values being associated with higher effective moisture [McDermott, 2004]. The strong correlation between $\delta^{18} \mathrm{O}$ and $\delta^{13} \mathrm{C}$ indicates that stalagmite calcite did not precipitate in isotopic equilibrium with its parent drip water, which is common for stalagmites forming in caves located in areas with a semiarid climate [e.g., Fleitmann et al., 2004; Burns et al., 2002]. At times of greater aridity and lower drip rates $\delta^{18} \mathrm{O}$ is more strongly affected by evaporation effects within the epikarst and Gejkar cave (lower humidity within the 

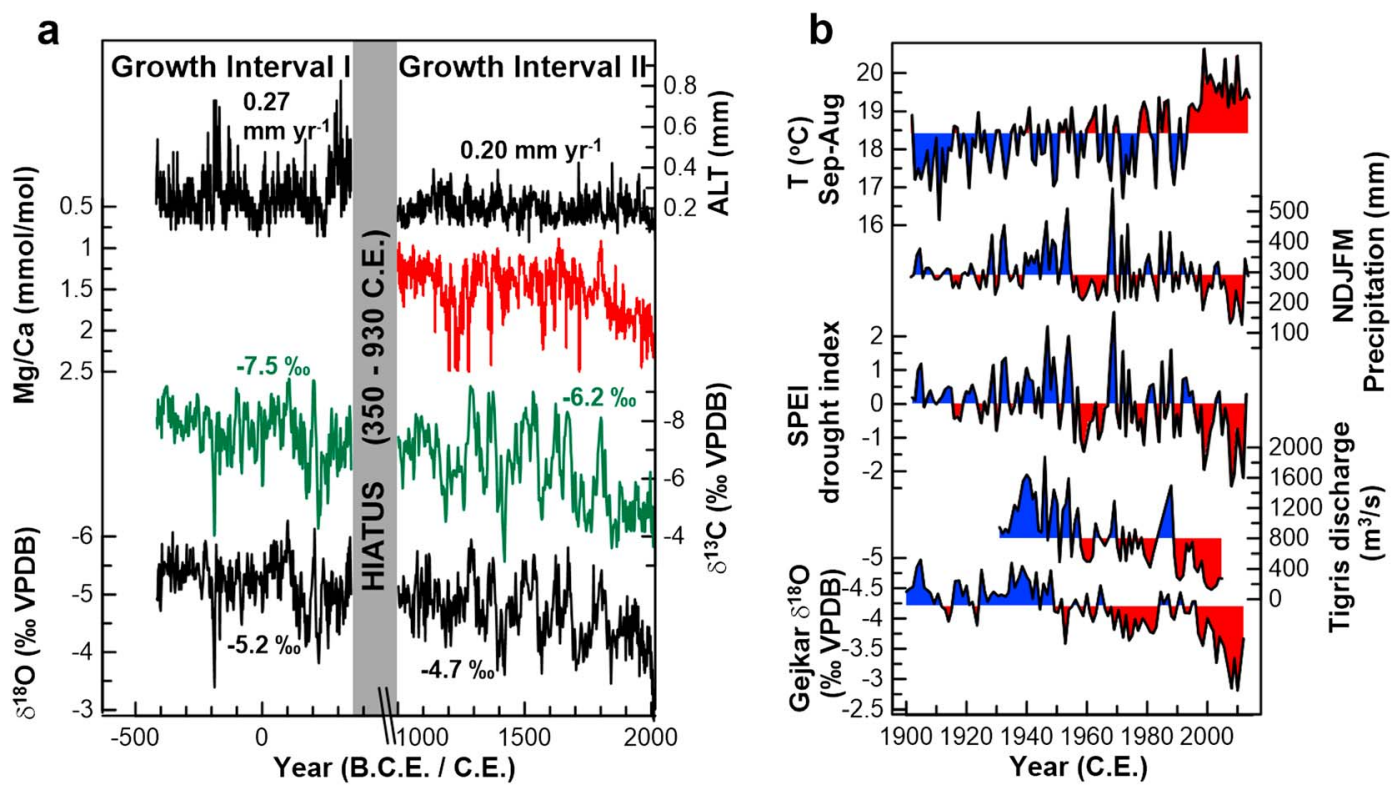

Figure 2. (a) Comparison between annual layer thickness (9-point running average), $\mathrm{Mg} / \mathrm{Ca}, \delta^{13} \mathrm{C}$, and $\delta^{18} \mathrm{O}$ profiles for Gej-1. (b) Comparison between the Gej-1 $\delta^{18} \mathrm{O}$ record with Tigris discharge at Kut [UN-ESCWA and BGR, 2013], SPEI drought index [Vicente-Serrano et al., 2010], November-December-January-February-March precipitation, and SeptemberAugust average temperature based on CRU data for the Gejkar $0.5^{\circ}$ grid cell [Harris et al., 2014].

cave) and $\delta^{13} \mathrm{C}$ by increased fractionation due to enhanced $\mathrm{CO}_{2}$ degassing as a result of lower drip rates [McDermott, 2004]. Both effects enhance any drought signals [Fleitmann et al., 2004]. Furthermore, changes in $\mathrm{Mg}$, a well-established proxy in stalagmites for groundwater residence time in karst aquifers [Treble et al., 2003)], are generally mimicking fluctuations in $\delta^{18} \mathrm{O}$ and $\delta^{13} \mathrm{C}$ (Figures 2a and S4). Higher Mg content, indicative of more arid climate conditions [Treble et al., 2003; Fairchild and Treble, 2009], coincides with more positive $\delta^{18} \mathrm{O}$ and $\delta^{13} \mathrm{C}$ values in stalagmite Gej-1.

Third, the Gej-1 proxies are in good agreement with meteorological observations for precipitation and temperature [Harris et al., 2014], regional drought indexes [Dai, 2011; Vicente-Serrano et al., 2010], and Tigris discharge [UN-ESCWA and BGR, 2013] (Figures 2b and S5). The good agreement between multiyear droughts since 1900 in the SPEl index and the Gej-1 $\delta^{18} \mathrm{O}$ record supports our assumption that the Gejkar record is a sensitive recorder of effective moisture. The Gej-1 record as such reflects agricultural droughts, which are of major importance for societies in the Fertile Crescent. When age uncertainties of the Gej-1 record are taken into account, fluctuations in $\delta^{18} \mathrm{O}$ values and $\mathrm{Mg}$ content appear to correlate well with historical accounts of dry and wet winters in Iraq [Vogt et al., 2011] (Figure 3a), although the historical data are not continuous and sometimes scarce (e.g., between 1250 and 1300 C.E). For instance, more frequent droughts at $~ 1230$ C.E. correspond well with elevated $\delta^{18} \mathrm{O}$ values and very high Mg content in the Gej-1 time series (Figure 3a).

Fourth, the Gejkar record is in good agreement with the Soreq Cave paleoprecipitation reconstruction from the Levant, particularly during the last 300 years (Figure S6) [Bar-Matthews et al., 2003]. Furthermore, in Gej-1 the long-term aridification trend during growth interval II is in good agreement with several other paleorecords from the Middle East, such as the Lake Nar $\delta^{18} \mathrm{O}$ record in Turkey [Jones et al., 2006], Quercus pollen in Lake Van in Turkey [Wick et al., 2003], Ti content in Lake Neor in Iran [Sharif et al., 2015], and the expansion of dry shrub-steppe in the Wadi Jarrah in the Khabur region in Northeast Syria [Kaniewski et al., 2012] (Figure 3b). These lines of evidence support our assumption that the Gej-1 multiproxy record is a faithful of recorder of effective moisture in northern Iraq and the wider FC.

\section{Multidecadal and Long-Term Droughts Recorded in the Gejkar Speleothem}

The Gej-1 proxies $\left(\delta^{18} \mathrm{O}, \delta^{13} \mathrm{C}\right.$, and $\mathrm{Mg}$ ) of effective moisture show several distinct features (Figures 2a and $3 \mathrm{~b}$ ). First, there is a clear offset between both growth intervals, with generally wetter conditions prevailing 

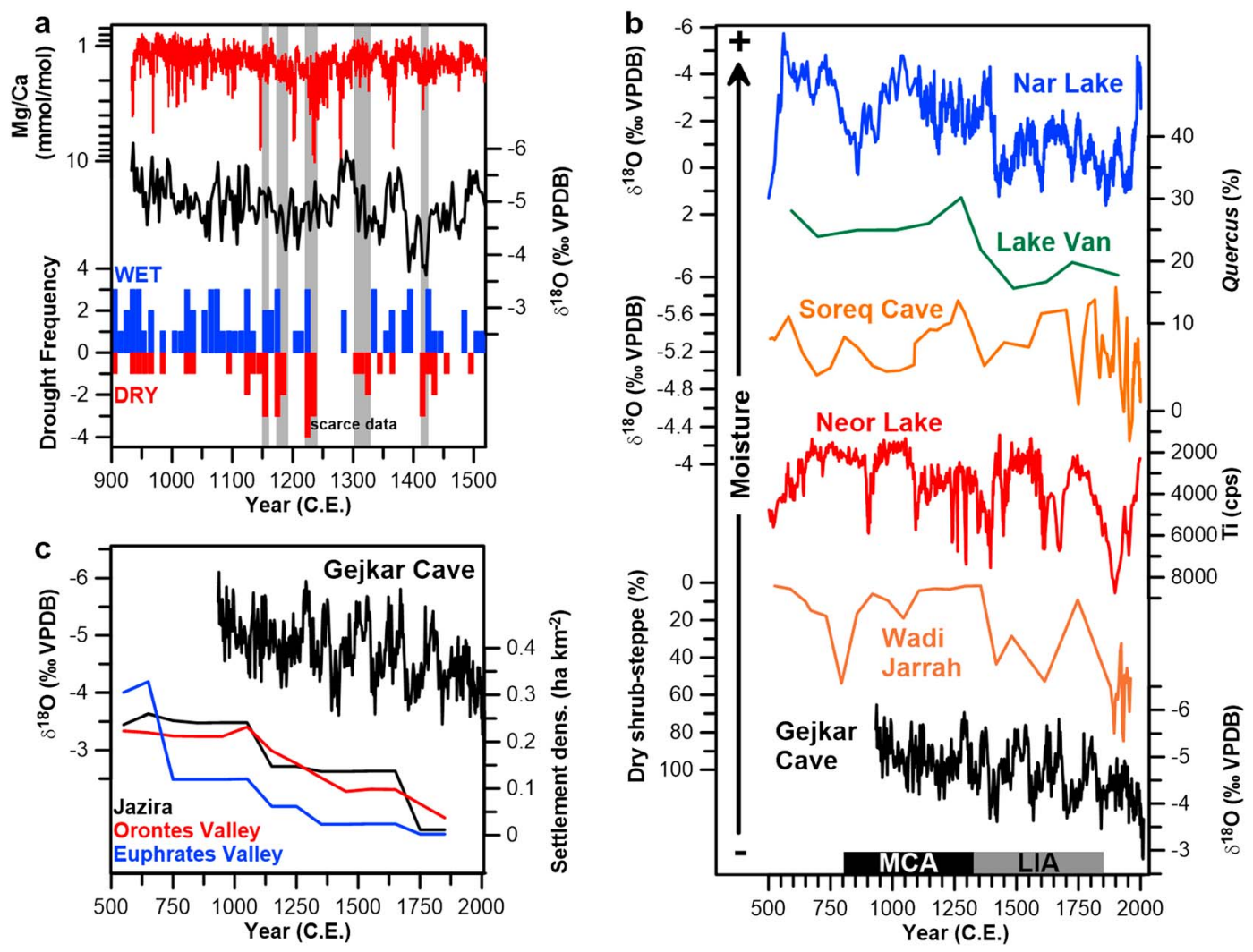

Figure 3. (a) Comparison between Gej-1 Mg/Ca and $\delta^{18} \mathrm{O}$ records with historical accounts for wet and dry winters per decade [Vogt et al., 2011]. The grey bars denote periods with more frequent droughts. (b) Comparison of the Gej- $1 \delta^{18} \mathrm{O}$ record with various other high-resolution proxy records for precipitation/moisture, the Lake Nar $\delta^{18} \mathrm{O}$ [Jones et al., 2006], Lake Van Quercus pollen \% [Wick et al., 2003], Soreq speleothem $\delta^{18} \mathrm{O}$ [Bar-Matthews et al., 2003], Lake Neor Ti [Sharifi et al., 2015], and Wadi Jarrah shrub-steppe indicating pollen [Kaniewski et al., 2012], and (c) archaeological settlement density for the Jazira (black), the Orontes (red), and the Euphrates regions (blue) [Lawrence et al., 2016] compared to the Gej-1 $\delta^{18} \mathrm{O}$ record.

between 400 B.C.E. and 100 C.E. (growth interval I). Supporting evidence for a more humid climate in the Middle East during this time interval comes from other records in the Middle East and Mediterranean (summarized in McCormick et al. [2012]). Second, the Medieval Climate Anomaly (MCA) and the Little Ice Age (LIA) are not easily discernable in the Gej-1 isotope and trace element profiles, although it appears that effective moisture was slightly higher and more stable during the MCA (Figure 3a). Interestingly, a distinct MCA/LIA pattern is also not apparent in other records from the Fertile Crescent, such as in the Soreq Cave [Bar-Matthews et al., 2003] and Lake Nar records [Jones et al., 2006]. Third, the Gej-1 records show a distinct long-term drying trend since at least 950 C.E., which is also evident in other proxy records from around the FC (Figure 3b). In Turkey, increasing $\delta^{18} \mathrm{O}$ in the Lake Nar [Jones et al., 2006] and declining Quercus pollen in Lake Van [Wick et al., 2003] reveal a progressive drying since $~ 600$ C.E. The long-term aridification trend is also supported by increasing dust content in Lake Neor sediments from Iran [Sharifi et al., 2015], less negative $\delta^{18} \mathrm{O}$ values in stalagmites from Soreq Cave [Bar-Matthews et al., 2003; Orland et al., 2009], and expansion of dry shrub-desert in the Khabur region [Kaniewski et al., 2012]. Fourth, in the Gej-1 $\delta^{18} \mathrm{O}$ profile distinct multidecadal variations in effective moisture occur, which are superimposed on the long-term drying trend, with the most severe drought lasting from the late 1990s until 2013 (further discussed below).

The persistent drought that started in the late 1990s is recorded by the Gej-1 $\delta^{18} \mathrm{O}$ record and corresponds to the multiyear meteorological and agricultural droughts of 1998-2000 and 2007-2010 in the FC [Trigo et al., 2010]. Both droughts resulted from a combination of lower precipitation and higher temperatures (so-called "hot droughts"; Figure 2b), which further reduced soil moisture through higher evapotranspiration and thereby exacerbated the agricultural drought. This puts the recent droughts in contrast to preceding arid episodes in the Middle East, which tended to coincide with colder temperatures [Guiot and Kaniewski, 2015]. The extreme recent droughts are also evident in the Soreq Cave record [Orland et al., 2014] and the Old World Drought Atlas (OWDA) derived from 

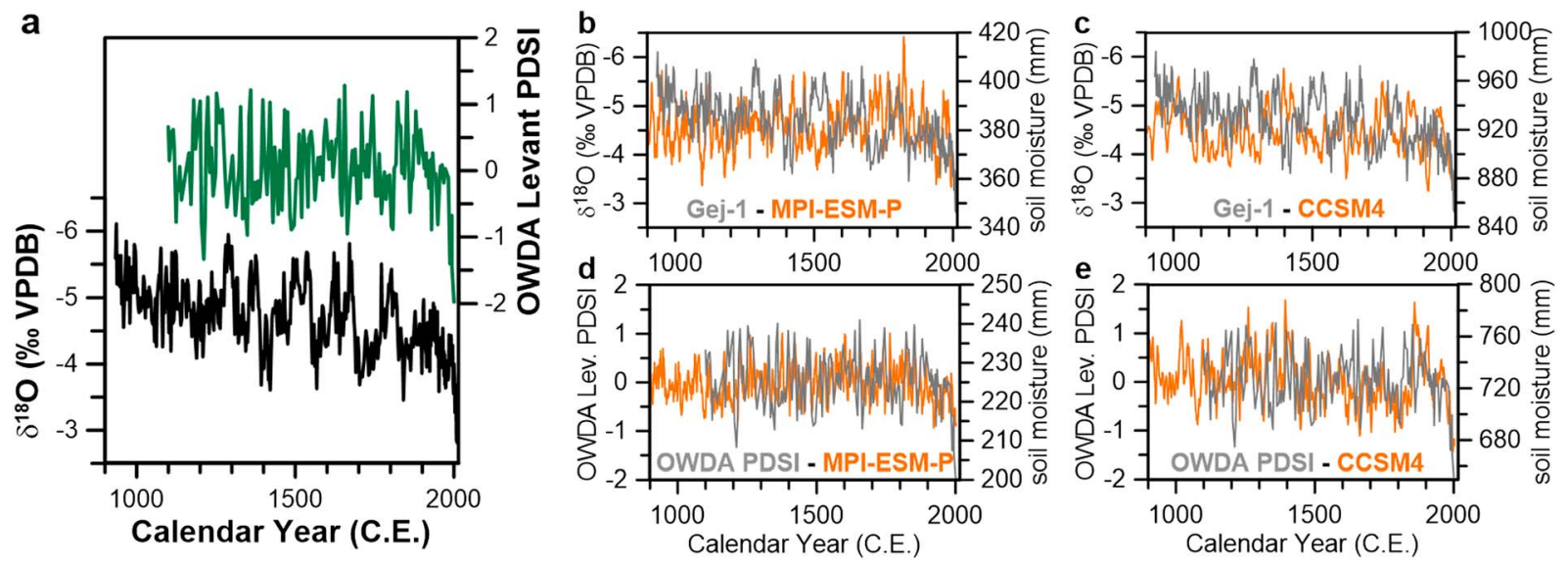

Figure 4. (a) Comparison between the Gej-1 $\delta^{18} \mathrm{O}$ with the smoothed Old World Drought Atlas (OWDA)-derived Palmer Drought Severity Index (PDSI) for the Levant [Cook et al., 2016] and (b and c) with soil moisture modeled by the MPI-ESM-P and CCSM4 models for northern Iraq, 11-point running average. (d and e) Comparison between the smoothed OWDA PDSI for the Levant with soil moisture for the Levant, 5-point running average.

tree ring records from the Levant region (Figure 3b). The latter indicates that the years between 1998 and 2012 were the most arid of at least the last 500 (98\% likelihood) or even the last 900 years ( $89 \%$ likelihood) [Cook et al., 2016]. The Gej-1 $\delta^{18} \mathrm{O}$ record clearly reveals that the recent droughts in the FC were the most severe since $\sim 930$ C.E, particularly if the long-term aridification trend since $\sim 950$ C.E. is also taken into account.

The Gej- $1 \delta^{18} \mathrm{O}$ record shows that the droughts since the late 1990s were not only severe as an absolute deviation from the recent mean hydroclimate, but they were also superimposed on a general aridification trend that commenced $\sim 950$ C.E. This is an important observation as the rather subtle multicentennial aridification trend in the FC exacerbated the vulnerability of agriculture/ecosystems and societies in this region to multiyear droughts by pushing famers in marginal areas in the FC closer to or even beyond the critical thresholds for rain-fed agriculture $\left(\sim 250 \mathrm{~mm} \mathrm{yr}^{-1}\right)$. Therefore, the millennial-scale aridification trend as visible in the Gej-1 $\delta^{18} \mathrm{O}$ record could have been an important contributing factor to the continuous decline in settlement numbers and intensity in the northern FC from 1100 C.E. onward [Lawrence et al., 2016] (Figure 3b). Socioeconomic factors, such as tax burdens, rapid dynastic successions, fragmentation, and invasions (e.g., by the Seljuqs and Mongols) [see Lawrence et al., 2016; Nissen and Heine, 2009], should certainly not be dismissed. Nevertheless, the long-term decrease in effective moisture in the $\mathrm{FC}$ would have led to a progressive decline in crop yields, which would have made it increasingly difficult to support a similar sized population [Kaniewski et al., 2012]. Consequently, a sedentary agricultural lifestyle would become increasingly difficult to sustain, accelerating nomadisation processes in the FC [Kaniewski et al., 2012].

While the clear long-term drying trend in the Gej-1 $\delta^{18} \mathrm{O}$ record is also documented by the Lake Nar [Jones et al., 2006], Lake Van [Wick et al., 2003], Lake Neor [Sharifi et al., 2015], Soreq Cave [Bar-Matthews et al., 2003; Orland et al., 2009], and Wadi Jarrah [Kaniewski et al., 2012] records (Figure 3b), it is missing from the Levantine tree ring-based reconstruction (Figures 4a and S7) [Cook et al., 2016], as well as from tree ringbased precipitation reconstructions for Turkey and Jordan (Figure S8) [Akkemik and Aras, 2005; D'Arrigo and Cullen, 2001; Touchan et al., 1999, 2003]. The most plausible explanation for this apparent mismatch could be that tree rings reflect spring and summer precipitation, while in the Middle East almost all precipitation occurs during winter (Figure S1). Furthermore, the detrending of tree ring records, which is necessary to remove non-climate related biological noise [Esper et al., 2003], may remove medium-term (decadal-century) and long-term (centuries-millennia) trends [Cook et al., 2015, 2016; Esper et al., 2003]. In either case, the importance of combining multiple paleoclimate proxy records to study both short- and long-term variations in effective precipitation is apparent. Tree ring records are often annually resolved and as such excellent indicators of short-term climatic variation, while speleothem and lake records are more capable to reveal the longterm trends on which such variations are superimposed.

The long-term, millennial-scale trend toward more arid conditions in the Fertile Crescent is most likely caused by transient changes in the Earth's orbit and associated changes in the frequency and path of cold-season 
storm tracks across the Middle East. Two model simulations (MPI-ESM-P and CCSM4) from the Coupled Model Intercomparison Project Phase 5 (CMIP5) [Taylor et al., 2012] were used for comparison with the Gej-1 $\delta^{18} \mathrm{O}$ and Levantine tree ring-based Palmer Drought Severity Index (PDSI) records to evaluate model skills in the FC. The data-model comparison (Figures $4 \mathrm{~b}-4 \mathrm{e}$ ) shows distinct differences in both multicentennial- and decadal-scale variations in effective moisture in the FC [Taylor et al., 2012] (Figures 4b-4e). The distinct long-term aridification trend and the amplitude of multidecadal-scale fluctuations in effective moisture in the Gej- $1 \delta^{18}$ O record are not captured by the MPI-ESM-P and CCSM4 models, while the agreement between the Levantine PDSI reconstruction and both models is also low.

Potential problems with paleo-hydroclimatic modeling have recently been highlighted [Ljungqvist et al., 2016], and there are several possible explanations for the diverging long-term trends and amplitude of multidecadal variations in soil moisture between the Gejkar $\delta^{18} \mathrm{O}$ record and both model simulations. First, the response of precipitation and atmospheric circulation in the FC to changes in orbital forcing may be too weak or not well represented in the models. Second, climate model simulations may have problems to simulate internal climate variability in the FC, possibly because resolution of both models is too coarse to capture the complex atmospheric dynamics and diverse topography in the Middle East. Third, simulated soil moisture may be too strongly dominated by temperature and evaporation, as shown for example by the increase in soil moisture in Iraq in the MPI-ESM-P model during the Little Ice Age and the recent trend toward more arid conditions in both models as a result of the temperature increase (Figure 2a compared to Figure 3b). Fourth, the proportion of summer precipitation is overestimated in the CCSM4 model, while in the FC this is negligible (Figure S9). Overall, the apparent differences between both climate models and proxy data indicate that the predicted hydroclimatic changes in the simulations are highly uncertain, particularly with respect to the frequency and severity of future droughts in the FC.

\section{Conclusions}

The Gej-1 record clearly reveals that the recent droughts of 1998-2000 and 2007-2010 were unprecedented since at least 950 C.E. They were not only the most severe deviations from the long-term climatic mean but they were also superimposed on a general aridification trend that began at 950 C.E. Clearly, the two recent droughts were not part of the natural hydroclimatic fluctuations (e.g., contra de Châtel [2014]). This regional knowledge is essential to correctly interpret effects of such droughts on societies in the in the Middle East (e.g., Gleick [2014] and Kelley et al. [2015] versus de Châtel [2014]). The long-term aridification trend since 950 C.E. could be a contributing factor for the general decline in settlement density in the northeastern FC. Furthermore, the long-term aridification trend in the FC/Middle East is not captured by two state-of-the-art climate models, indicating that further improvement of these models is necessary to correctly inform policy makers. Although current models predict increasingly dry conditions for the Middle East [Christensen et al., 2013; Dai, 2013], it is nonetheless possible that they are underestimating the actual severity of droughts in this vulnerable region.

Acknowledgments

The data are available in the supplementary information, will be deposited in the NOAA archive, and can be obtained from the corresponding authors. We are very grateful to Mark Altaweel and Tim Atkinson of University College London for supplying information about Gejkar Cave.

\section{References}

Akkemik, U., and A. Aras (2005), Reconstruction (1689-1994 AD) of April-August precipitation in the southern part of central Turkey, Int. J. Climatol., 25, 537-548.

Bar-Matthews, M., A. Ayalon, M. Gilmour, A. Matthews, and C. Hawkesworth (2003), Sea-land oxygen isotopic relationships from planktonic forminifera and speleothems in the Eastern Mediterranean region and their implication for paleorainfall during interglacial intervals, Geochim. Cosmochim. Acta, 67(17), 3181-3199.

Braconnot, P., S. P. Harrison, M. Kageyama, P. J. Bartlein, V. Masson-Delmotte, A. Abe-Ouchi, B. Otto-Bliesner, and Y. Zhao (2012), Evaluation of climate models using palaeoclimatic data, Nat. Clim. Change, 2(6), 417-424.

Burns, S. J., D. Fleitmann, M. Mudelsee, U. Neff, A. Matter, and A. Mangini (2002), A 780-year annually resolved record of Indian Ocean monsoon precipitation from a speleothem record from south Oman, J. Geophys. Res., 170(D20), 4434, doi:10.1029/2001JD001281.

Cheng, H., et al. (2013), Improvements in ${ }^{230}$ Th dating, ${ }^{230}$ Th and ${ }^{234} \mathrm{U}$ half-life values, and U-Th isotopic measurements by multi-collector inductively coupled plasma mass spectrometry, Earth Planet. Sci. Lett., 371, 82-91.

Christensen, J. H., et al. (2013), Climate phenomena and their relevance for future regional climate change, in Climate Change 2013: The Physical Science Basis. Contribution of Working Group I to the Fifth Assessment Report of the Intergovernmental Panel on Climate Change, edited by T. F. Stocker et al., Cambridge Univ. Press, Cambridge.

Cook, B. I., K. J. Anchukaitis, R. Touchan, D. M. Meko, and E. R. Cook (2016), Spatiotemporal drought variability in the Mediterranean over the last 900 years, J. Geophys. Res. Atmos., 121, 2060-2074, doi:10.1002/2015JD023929.

Cook, E. R., et al. (2015), Old world megadroughts and pluvials during the Common Era, Sci. Adv., 1(10), 1-9.

Crowley, T. J., and M. B. Unterman (2013), Technical details concerning development of a 1200 yr proxy index for global volcanism, Earth Syst. Sci. Data, 5(1), 187-197. 
D'Arrigo, R., and H. M. Cullen (2001), A 350-year (AD 1628-1980) reconstruction of Turkish precipitation, Dendrochronologia, 19(2), 169-177.

Dai, A. G. (2011), Characteristics and trends in various forms of the Palmer Drought Severity Index during 1900-2008, J. Geophys. Res., 116, D19112, doi:10.1029/2011JD016410.

Dai, A. G. (2013), Increasing drought under global warming in observations and models, Nat. Clim. Change, 3(1), 52-58.

de Châtel, F. (2014), The role of drought and climate change in the Syrian uprising: Untangling the triggers of revolution, Middle Eastern Stud., 50(4), 521-535.

Esper, J., E. R. Cook, P. J. Krusic, K. Peters, and F. H. Schweingruber (2003), Tests of the RCS method for preserving low-frequency variability in long tree-ring chronologies, Tree-Ring Res., 59(2), 81-98.

Fairchild, I. J., and P. C. Treble (2009), Trace elements in speleothems as recorders of environmental change, Quat. Sci. Rev., 28(5-6), 449-468.

Fleitmann, D., S. J. Burns, U. Neff, M. Mudelsee, A. Mangini, and A. Matter (2004), Palaeoclimatic interpretation of high-resolution oxygen isotope profiles derived from annually laminated speleothems from Southern Oman, Quat. Sci. Rev., 23(7-8), 935-945.

Fleitmann, D., et al. (2007), Holocene ITCZ and Indian monsoon dynamics recorded in stalagmites from Oman and Yemen (Socotra), Quat. Sci. Rev., 26(1-2), 170-188.

Gao, C. C., A. Robock, and C. Ammann (2008), Volcanic forcing of climate over the past 1500 years: An improved ice core-based index for climate models, J. Geophys. Res., 113, D23111, doi:10.1029/2008JD010239.

Gent, P. R., et al. (2011), The Community Climate System Model version 4, J. Clim., 24(19), 4973-4991.

Giorgetta, M. A., et al. (2013), Climate and carbon cycle changes from 1850 to 2100 in MPI-ESM simulations for the Coupled Model Intercomparison Project phase 5, J. Adv. Model. Earth Syst., 5(3), 572-597, doi:10.1002/jame.20038.

Giorgi, F. (2006), Climate change hot-spots, Geophys. Res. Lett., 33, L08707, doi:10.1029/2006GL025734.

Gleick, P. H. (2014), Water, drought, climate change, and conflict in Syria, Weather Clim. Soc., 6(3), 331-340.

Greve, P., B. Orlowsky, B. Mueller, J. Sheffield, M. Reichstein, and S. I. Seneviratne (2014), Global assessment of trends in wetting and drying over land, Nat. Geosci., 7(10), 716-721.

Guiot, J., and D. Kaniewski (2015), The Mediterranean Basin and Southern Europe in a warmer world: What can we learn from the past?, Front. Earth Sci., 3, 28.

Harris, I., P. D. Jones, T. J. Osborn, and D. H. Lister (2014), Updated high-resolution grids of monthly climatic observations-The CRU TS3.10 dataset, Int. J. Climatol., 34(3), 623-642.

Held, I. M., and B. J. Soden (2006), Robust responses of the hydrological cycle to global warming, J. Clim., 19(21), 5686-5699.

Jones, M. D., C. N. Roberts, M. J. Leng, and M. Turkes (2006), A high-resolution late Holocene lake isotope record from Turkey and links to North Atlantic and monsoon climate, Geology, 34(5), 361-364.

Joodaki, G., J. Wahr, and S. Swenson (2014), Estimating the human contribution to groundwater depletion in the Middle East, from GRACE data, land surface models, and well observations, Water Resour. Res., 50, 2679-2692, doi:10.1002/2013WR014633.

Kaniewski, D., E. Van Campo, and H. Weiss (2012), Drought is a recurring challenge in the Middle East, Proc. Natl. Acad. Sci. U.S.A., 109(10), 3862-3867.

Kelley, C. P., S. Mohtadi, M. A. Cane, R. Seager, and Y. Kushnir (2015), Climate change in the Fertile Crescent and implications of the recent Syrian drought, Proc. Natl. Acad. Sci. U.S.A., 112(11), 3241-3246.

Lawrence, D., G. Philip, H. Hunt, L. Snape-Kennedy, and T. J. Wilkinson (2016), Long term population, city size and climate trends in the fertile crescent: A first approximation, Plos One, 11(6), doi:10.1371/journal.pone.0157863.

Ljungqvist, F. C., P. J. Krusic, H. S. Sundqvist, E. Zorita, G. Brattström, and D. Frank (2016), Northern hemipshere hydroclimate variability over the past twelve centuries, Nature, 532, 94-98.

McCormick, M., et al. (2012), Climate change during and after the Roman Empire: Reconstructing the past from scientific and historical Evidence, J. Interdiscip. History, 43(2), 169-220.

McDermott, F. (2004), Palaeo-climate reconstruction from stable isotope variations in speleothems: A review, Quat. Sci. Rev., 23, 901-918.

Nissen, H. J., and P. Heine (2009), From Mesopotamia to Iraq. A Concise History, Univ. of Chicago Press, Chicago.

Orland, I. J., M. Bar-Matthews, N. T. Kita, A. Ayalon, A. Matthews, and J. W. Valley (2009), Climate deterioration in the Eastern Mediterranean as revealed by ion microprobe analysis of a speleothem that grew from 2.2 to 0.9 ka in Soreq Cave, Israel, Quat. Res., 71, 27-35.

Orland, I. J., Y. Burstyn, M. Bar-Matthews, R. Kozdon, A. Ayalon, A. Matthews, and J. W. Valley (2014), Seasonal climate signals (1990-2008) in a modern Soreq Cave stalagmite as revealed by high-resolution geochemical analysis, Chem. Geol., 363, 322-333.

Rasmussen, S. O., et al. (2006), A new Greenland ice core chronology for the last glacial termination, J. Geophys. Res., 111, D06102, doi:10.1029/2005JD006079.

Schmidt, G. A., et al. (2011), Climate forcing reconstructions for use in PMIP simulations of the last millennium (v1.0), Geosci. Model Dev., 4(1), 33-45.

Sharifi, A., et al. (2015), Abrupt climate variability since the last deglaciation based on a high-resolution, multi-proxy peat record from NW Iran: The hand that rocked the Cradle of Civilization?, Quat. Sci. Rev., 123, 215-230.

Sheffield, J., E. F. Wood, and M. L. Roderick (2012), Little change in global drought over the past 60 years, Nature, 491(7424), 435-440.

Tanner, S. D., V. I. Baranov, and D. R. Bandura (2002), Reaction cells and collision cells for ICP-MS: A tutorial review, Spectrochim. Acta Part B-At. Spectrosc., 57(9), 1361-1452.

Taylor, K. E., R. J. Stouffer, and G. A. Meehl (2012), An overview of CMIP5 and the experiment design, Bull. Am. Meteorol. Soc., 93(4), 485-498.

Touchan, R., D. Meko, and M. K. Hughes (1999), A 396-year reconstruction of precipitation in southern Jordan, J. Am. Water Resour. Assoc., 35(1), 49-59.

Touchan, R., G. M. Garfin, D. M. Meko, G. Funkhouser, N. Erkan, M. K. Hughes, and B. S. Wallin (2003), Preliminary reconstructions of spring precipitation in southwestern Turkey from tree-ring width, Int. J. Climatol., 23(2), 157-171.

Treble, P., J. M. G. Shelley, and J. Chappell (2003), Comparison of high resolution sub-annual records of trace elements in a modern (1911-1992) speleothem with instrumental climate data from southwest Australia, Earth Planet. Sci. Lett., 216(1-2), 141-153.

Trigo, R. M., C. M. Gouveia, and D. Barriopedro (2010), The intense 2007-2009 drought in the Fertile Crescent: Impacts and associated atmospheric circulation, Agric. For. Meteorol., 150(9), 1245-1257.

Ulbrich, U., et al. (2012), Climate of the Mediterranean: Synoptic patterns, temperature, precipitation, winds, and their extremes, in The Climate of the Mediterranean Region: From the Past to the Future, edited by P. Lionello, Elsevier, Amsterdam.

UN-ESCWA, and BGR (2013), Inventory of Shared Water Resources in Western Asia, United Nations, New York.

van Oldenborgh, G. J. (2016), KNMI Climate Explorer. [Available at https://climexp.knmi.nl, last accessed 01/03/2016.] 
Vicente-Serrano, S. M., S. Begueria, J. I. Lopez-Moreno, M. Angulo, and A. El Kenawy (2010), A new global 0.5 degrees gridded dataset (1901-2006) of a multiscalar drought index: Comparison with current drought index datasets based on the Palmer Drought Severity Index, J. Hydrometeorol., 11(4), 1033-1043.

Vieira, L. E. A., S. K. Solanki, N. A. Krivova, and I. Usoskin (2011), Evolution of the solar irradiance during the Holocene, Astron. Astrophys., 531, doi:10.1051/0004-6361/201015843.

Vogt, S., R. Glaser, J. Luterbacher, D. Riemann, G. Al Dyab, J. Schoenbein, and E. Garcia-Bustamante (2011), Assessing the Medieval Climate Anomaly in the Middle East: The potential of Arabic documentary sources, PAGES News, 19(1), 28-29.

Wick, L., G. Lemcke, and M. Sturm (2003), Evidence of Lateglacial and Holocene climatic change and human impact in eastern Anatolia: High-resolution pollen, charcoal, isotopic and geochemical records from the laminated sediments of Lake Van, Turkey, Holocene, 13(5), $665-675$. 